\title{
PARAPROBİYOTİKLER, POSTBİYOTİKLER VE SAĞLIK ÜZERİNE ETKİLERİ
}

\author{
Esra Uğur *, Atilla Bektaş ${ }^{2}$ Meltem Ulusoy ${ }^{3}$ Zübeyde Öner ${ }^{1}$ \\ ${ }^{1}$ Süleyman Demirel Üniversitesi, Gıda Mühendisliği Bölümü, Isparta, Türkiye \\ ${ }^{2}$ Özel Ankara Cerrahi Tip Merkezi, Gastroenteroloji Bölümü, Öveçler, Ankara, Türkiye \\ ${ }^{3}$ Hacettepe Üniversitesi, Biyoloji bölümü, Uygulamalı Biyoloji Anabilim Dalı, Ankara, Türkiye
}

Geliş / Received: 19.12.2020; Kabul / Accepted: 15.03.2021; Online bask1 / Published online: 22.03.2021

Uğur, E., Bektaş A., Ulusoy, M., Öner, Z. (2021). Paraprobiyotikler, postbiyotikler ve sağllk üzerine etkileri. GIDA (2021) 46(2) 428-442 doi: 10.15237/gida. GD20141.

Uğur, E., Bektass A., Ulusoy, M., Öner, Z. (2021). Paraprobiotics, postbiotics and their effects on health. GIDA (2021) 46(2) $428-442$ doi: $10.15237 /$ gida. GD20141.

\section{ÖZ}

İnsan gastrointestinal kanalı (GIT), sindirimde, immünolojide ve bazı hastalıkların oluşumunda önemli rol oynayan zengin, karmaşık bir mikrobiyota içerir. Normal şartlar altında, bağırsak mikrobiyotasının bileşimi kararlıdır. Ancak diyetteki değişiklikler, bazı ilaçlanın kullanımı ve stres gibi faktörler nedeniyle mikrobiyotanın bileşimi değişebilir. Bağırsak mikrobiyotasını düzenlemek amacıyla yeterli miktarda alındıklannda konağa fayda sağlayan bakteri ve maya gibi canlı mikroorganizmalar olarak tanımlanan probiyotiklerin, g1da şeklinde ya da gida takviyesi olarak alınması günümüzde yaygın ve bilinen bir yöntemdir. Son yıllarda, cansız (inaktif) mikroorganizmalar olan paraprobiyotiklerin veya canlı bakterilerden salınan ya da bakteriyel parçalanma sonrasında ortaya çıkan metabolik yan ürünler olan postbiyotiklerin, probiyotikler yerine alternatif olarak kullanımı söz konusudur. Paraprobiyotik ve postbiyotikler uygulandıklan konakçıda tupk1 probiyotikler gibi başta bağırsak sağlı̆̆ını düzenleme ve immün sistemini güçlendirme gibi birçok sağlık etkileri göstermektedir. Bu çalışmada, probiyotikler yerine kullanılabilecek ve benzer sağllk etkileri sağlayabilen paraprobiyotikler ve postbiyotikler ile ilgili çalısmalar derlenmiştir.

Anahtar kelimeler: Paraprobiyotik, postbiyotik, bağırsak sağlı̆̆1, bağışıklık sistemi

\section{PARAPROBIOTICS, POSTBIOTICS AND THEIR EFFECTS ON HEALTH}

\section{ABSTRACT}

The human gastrointestinal tract (GIT) contains a rich, complex microbiota that plays an important role in digestion, immunology, and the occurrence of certain diseases. Under normal conditions, the composition of the gut microbiota is stable. However, the composition of the microbiota may change due to changes in diet, use of certain medications and stress. Today, it is a common and known method to take probiotics, which are defined as living microorganisms such as bacteria, yeast, when taken in sufficient quantities to regulate the intestinal microbiota, in the form of food or as a food supplement. In recent years, the use of paraprobiotics, which are non-living (inactive) microorganisms, or postbiotics, which are metabolic by-products released from living bacteria or after bacterial degradation, have started to attract attention as an alternative to probiotics.

\footnotetext{
* Yazışmalardan sorumlu yazar / Corresponding author esra.ugr@hotmail.com
}

GSM: 05386233702

Esra Uğur; ORCID no: 0000-0003-0457-723X

Zübeyde Öner; ORCID no: 0000-0003-2557-0731

Atilla Bektaş; ORCID no: 0000-0001-7775-3770

Meltem Ulusoy ORCID no: 0000-0002-3885-2714 
Paraprobiotics and postbiotics demonstrate many health effects such as regulating intestinal health and strengthening the immune system, just like probiotics, in the hosts where they are applied. In this study, studies on paraprobiotics and postbiotics that can be used instead of probiotics and provide similar health effects are reviewed.

Keywords: Paraprobiotic, postbiotic, intestinal health, immune system

\section{GİRIŞ}

İnsan vücudundaki gastrointestinal kanalda kolonize olan bakteri, virüs, maya, protozoa gibi mikroorganizmalardan oluşan ve bir organ gibi işlevi olan ekosisteme "bağırsak mikrobiyotası (mikroflorası)" denilmekte ve literatürde bağırsak mikrobiyotasının, insan sağlığı ile ilişkili olduğuna dair çok sayıda çalısma bulunmaktadır (Young, 2017). Mikrobiyota gelişimini, bileşimini ve fonksiyonunu etkileyen faktörler arasında; doğum şekli, annenin mikrobiyotası, anne sütü alımı, antibiyotik/probiyotik kullanımı ve beslenme şekli yer almaktadır (Palmer vd., 2007). Bu faktörler arasında beslenme, mikrobiyota oluşumu ve modülasyonu üzerinde $\% 57$ oranında etkili olmaktadır. Bu nedenle yeterli ve dengeli bir beslenmeyle beraber makro besin ve mikro besinlerin alınmasının yanı sıra; doğal prebiyotik ve probiyotik gıda tüketimi ön plana çıkmaktadır (Baothman vd., 2016; Bektaş vd., 2020a). Beslenmeyle yeterli miktarda doğal prebiyotik ve probiyotik alımı için "Akdeniz diyeti" önerilmekle birlikte tüm dünyada "Batı tarzı beslenme" şeklinin yaygınlaşmasıyla fazla miktarda hayvansal doymuş yağ içeren işlenmiş ve rafine edilmiş gıda tüketimi artmaktadır (Bektaş vd., 2020b). Bu beslenme tarzı, vücuttaki canlı mikroorganizma topluluğu olan mikrobiyotayı olumsuz etkilemekte ve birçok kronik hastalığa zemin hazırlayan bozulmuş, sağlıksız mikrobiyotaya (disbiyozis) neden olmaktadır. Bağırsak mikrobiyotasındaki dengesizliğin giderilmesi, bağırsak sağlığının iyileşmesi veya modülasyonunu sağlamak amaciyla günümüzde gıda ve ilaç sanayisinde probiyotik, prebiyotik, paraprobiyotik ve postbiyotik gida takviyeleri ve reçetesiz satılan farmasotik ürünlerin kullanımı önem kazanmaktadır.

Günümüzde beslenme ve sağllk konularnna olan ilginin artması ile insan sağlığını koruyan, iyileştiren ve hastalık oluşma riskini azaltan fonksiyonel gidalara olan talep artmıştır. Fonksiyonel gidaların en önemli grubunu probiyotik mikroorganizma içeren gidalar oluşturmaktadır. Probiyotikler yeterli miktarda alındığında konakçıya sağlık yararı sağlayan canlı mikroorganizmalar olarak tanımlamaktadır (Buran, 2020). Gidalarda genellikle Bifidobacterium spp. ve Lactobacillus spp. gibi bakteriler ile Saccharomyces spp. gibi mayalar, probiyotik olarak kullanılan en yaygın mikroorganizmalardır. Normalde mikrobiyotada bulunan probiyotik mikroorganizmalar (bakteri ve maya hücresi), dışarıdan doğal olarak gıdalarla, gıda takviyeleri olarak çeşitli gidalara ilave edilerek veya farmasotik şekillerde (tablet, kapsül, toz, şase, damla vb.) alınabilmektedir (Yangilar 2015).

Son yıllarda yapılan çalışmalar ile canlı olmayan mikroorganizmaların ve bunların bileşenlerinin de tıpk1 probiyotikler gibi sağlık etkisi gösterdiği anlaşılmıştır. Söz konusu bu canlı olmayan mikroorganizmalara genel olarak paraprobiyotik denilmektedir. Paraprobiyotikler yeterli miktarda tüketildiğinde fayda sağlayan, canlı olmayan mikrobiyel hücreler (bozulmamış veya parçalanmış) veya işlenmemiş hücre özütleri olarak tanımlanmaktadır (Martín ve Langella, 2019). Postbiyotikler ise hücre metabolitleri, biyojenikler, hücresiz süpernatant, fonksiyonel proteinler/enzimler, hücre dışı polisakkaritler (EPS), teikoik asit, pili tipi yapılar, metabiyotikler (mikrobiyota metabolitleri) ve probiyotik aktivitenin metabolik atıklar1 olarak tanımlanmaktadır (Malashree vd., 2019; Wegh vd., 2019). Fermente süt ürünlerindeki laktik asit bakterileri (LAB), laktik asit, peptidoglikan, bakteriyosin ile postbiyotik olabilecek metabolitleri salgılayarak sağlık açısından fayda sağlarlar. Örneğin, fermantasyonla üretilen laktat ve kısa zincirli yağ asitlerinin (KZYA) birer postbiyotik olduğu ve bağırsaktaki antienflamatuar ve antikarsinojenik özellikleri etkilediği bildirilmiştir (Iraporda vd., 2015; Wu vd., 2018; Malashree vd., 2019). Bugüne kadar en çok bilinen laktat, çeşitli peptitler, KZYA, galaktooligosakkaritler gibi farklı postbiyotiklerin, 
Lactobacillus ve Bifidobacterium bakterilerine ait suşlar tarafindan bağırsakta veya gida sistemlerindeki fermantasyonla üretildiği bilinse de Streptococcus ve Faecalibacterium gibi birçok bakteri veya maya tarafindan da postbiyotik sayılabilecek metabolitlerin üretildiği bilinmektedir (Aguilar-Toalá vd., 2018; Collado, vd., 2019).

Gida sistemlerinde postbiyotik ve paraprobiyotiklerin kullanılması için öncelikle detaylı bir şekilde tanımlanmış ve karakterizasyonunun iyi bir şekilde yapılmıș olmas1 gerekmektedir. Postbiyotiklerde metabolitlerin tanımlanması, paraprobiyotiklerde ise bozulmamış hücrelerdeki bütünlügün veya değişikliklerin değerlendirilmesi için kullanılan tekniklerin ve analitik araçların seçimi, analitik amaçlara, mikrobiyel komplekslerin niteliksel ve/veya niceliksel özelliklerine ve incelenen moleküllere bağlıdır (Shenderov vd., 2020). Ek olarak, bunların fonksiyonel amaçlarla üretimini uygun maliyetle sağlamak için kullanilabilecek teknolojik ve endüstriyel süreçler üzerinde çalışılmasına da ihtiyaç duyulmaktadır. Bu amaçla Dunand vd. (2019) yaptıkları çalışmada hem laboratuvar hem de endüstriyel ölçekte postbiyotik üretiminin, biyoaktivitelerinde ve/veya koruyucu etkilerinde farkllik oluşturmadığ1 sonucuna varmışlardır. Son olarak, postbiyotik / paraprobiyotik ile yapilan sinırlı sayıdaki çalışmalarda, probiyotiklerde olduğu gibi yararlı etki sağlamak için gerekli olan spesifik bir doz belirlenmesi, bunlar için henüz tam olarak saptanmamıştır (Nataraj vd., 2020). Bunun için gelecekteki çalışmalarda, in vitro aktivitelerinin ve in vivo etkilerinin biyoaktivitelerini daha iyi anlamak için mekanistik çalışmalara odaklanılmalıdır.

\section{PROBIYYOTIKK YERINNE PARAPROBIYYOTIIK VE POSTBIYYOTIIK KULLANIMI}

Bir mikroorganizmanın probiyotik olarak nitelendirilmesi için bağırsağa kadar canlılığını kaybetmeden ulaşması ve bağırsak çeperine tutunabilme yeteneğinin olması gerekir. Test edilen probiyotik suşları, gelişme ortamı, inkübasyon sicaklığı ve ön işlem yöntemleri gibi üretim süreci koşullarnndan önemli ölçüde etkilenmektedir. Probiyotik suşlarnn bu tip koşullardan etkilenmesi, belirli gidalarda kullanımında bazı teknolojik zorluklar getirmektedir. Türk Gıda Kodeksi'ne göre, bir gıdanın probiyotik ürün olarak kabul edilmesi için en az $10^{6} \mathrm{KOB} / \mathrm{g}$ ya da $\mathrm{ml}$ canlı probiyotik bakteri içermesi ve bunu muhafaza etmesi gerektiği bildirilmiştir (Anonymous, 2006). Probiyotiklerin canlı olma gereksinimi, bunların belirli gidalarda kullanımını zorlaştırmaktadır. Böylece aynı faydaları sağlayan paraprobiyotiklerin ve postbiyotiklerin üretimi ön plana çımaktadır. Teknolojik olarak üretimi sirasında yüksek isıl işlem gereken ürünlere kolay ilave edilebilmeleri, canlılık kaybı problemi olmadığı için soğuk zincir gereksiniminin olmaması, depolama ve taşıma kolaylĭğ1, az gelişmiş bölgelere ürün dağıtım ve satışının kolay olması gibi avantajları nedeniyle g1dalarda probiyotikler yerine paraprobiyotiklerin ve postbiyotiklerin kullanılması giderek önem kazanmaktadır.

Probiyotikler de dahil olmak üzere canlı bakterilerin sağık uygulamalarında kullanımı firsatç1 patojenite gelişimine neden olabilmektedir. Bu durum bağışıklık sistemi zayıf bireyler için risk oluşturmakta ve yoğun bakım hastalarında, bağırsak bütünlüğü bozulmuş aktif kanamalı hastalarda (örneğin şiddetli inflamatuar bağırsak hastalığı- IBH) ve şiddetli pankreatit durumunda probiyotik kullanılmasi önerilmemektedir (Singhi vd., 2016). Canlı mikroorganizma yerine inaktive edilmiş mikroorganizma ve hücre özütlerinin kullanılmasi; immün sistemi zaylf ya da baskılanmış bireylerde enfeksiyon veya enflamasyon riski oluşturmadığı için probiyotiklere göre daha fazla güvenlik faktörünün olması, depolama ve dağıtım seçeneklerindeki kolaylıklar nedeniyle de ürünlerde kullanım kolaylığ1 sunması gibi avantajlar sağlamaktadır (Sawada vd., 2016; Warda vd., 2019).

Gida sistemlerinde probiyotiklerin kullanımına alternatif olarak geliştirilen paraprobiyotikler; DNA filamentlerinin kırlmas1, hücre zar1 bozulması veya hücre duvarının mekanik hasarı 
gibi mikrobiyel hücre yapılarını değiştiren faktörlere maruz kalıp hücre canliliklarını tamamen kaybeden mikroorganizmalardır. Ek olarak, temel enzimlerin etkisizleştirilmesi veya membran seçiciliğinin devre dışı bırakılması gibi mikrobiyel fizyolojik fonksiyonlardaki değişiklikler de canlılık kaybına neden olur. Canlı bakterilerin inaktivasyonu ile paraprobiyotik elde etmek amaciyla çeşitli yöntemler literatürde uygulanmıştır. Bunlar 1sıl işlem, kimyasallar (ör. formalin), gama veya ultraviyole işınlama, sonikasyon ve ohmik 1sitmadır (de Almada vd., 2016; Tiptiri-Kourpeti vd., 2016). Uygulanan işlemler ve normları, hücrenin bütünlüğü üzerinde farklı etkilere sahiptir. $\mathrm{Bu}$ etkiler işlemin yoğunluğu, işlemin türü ve uygulanma süresine göre değişmekle birlikte elde edilen paraprobiyotiğin sağlık faydaları üzerinde de etkilidir.

Postbiyotikler, canli probiyotik mikroorganizmalar tarafindan üretilen veya hücre kirllmasından sonra konağa herhangi bir fizyolojik fayda sağlayan biyoaktif çözünür faktörler (ürünler veya metabolik yan ürünler) olarak tanımlanır. Moleküler ağırlığ 50 ila 100 kDa olan, çözünür, cansız bakteri ürünleri olan postbiyotiklerin konakçı üzerinde biyolojik aktiviteleri olduğu bilinmektedir. Postbiyotik üretimi genellikle 1sı ve enzimatik işlemler, çözücü ekstraksiyonu ve sonikasyon gibi hücre parçalama tekniklerini içerir. Ardından ilave bir ekstraksiyon ve santrifüj, diyaliz, dondurularak kurutma ve kolon saflaştırma gibi üretim sonrasındaki işlemler, üretim prosedürleri elde etmeye yardımc1 olmak için kullanılmaktadır (Aguilar-Toalá vd., 2018).

In vitro ve in vivo çalsşmalar; postbiyotiklerin ve paraprobiyotiklerin antienflamatuar, immünomodülatör, antioksidan ve antimikrobiyel gibi biyoaktiviteler ile antikarsinojenik, antiproliferatif faydalar gösterdiğini ortaya koymaktadır. Paraprobiyotikler; alkolün yol açtı̆̆1 karaciğer hastalıkları, solunum yolu hastalıkları, ishal, inflamatuar bağırsak hastalıkları, antienflamatuar, bağışıklık sistemi ve bağırsak mikrobiyotasının bakteriyel translokasyonunu modüle etmek gibi farklı amaçlar için kullanılmış ve literatürde olumlu etkiler göstermiştir. Diğer faydalı etkileri; laktoz intoleransinın azaltılması, diş çürügünün iyileştirilmesi, yaşlanma belirtilerinin yavaşlatılması ve kanser hücrelerinin büyümesini kontrol etmesidir (de Almada vd., 2016; Sharma ve Shukla, 2016; Posadas vd., 2017; Aguilar-Toalá vd.,2019; Chuah vd., 2019; de Oliveira Coelho vd., 2019; Moradi vd., 2019; Riaz Rajoka vd., 2019; Cuevas-González vd., 2020).

\section{BAĞIŞIKLIK SİSTEMİ ÜZERINNE YAPILMIŞ ÇALIŞMALAR}

Probiyotikler gibi paraprobiyotikler bağışıklık sistemine etki ederler ve bağışıklığı düzenleme üzerindeki etkileri hakkında literatürdeki çeşitli raporlar bulunmaktadır. Paraprobiyotik uygulamasının doğuştan gelen bağışıklık hücrelerinden olan makrofajların tepkisini in vitro olarak arttırdığı ve enfeksiyonlara karşı bağışıklık sistemi üzerinde bir etki yarattı̆̆ yapılan çalışmalarla gözlenmiştir. Paraprobiyotik elde etmek için uygulanan 1si ile inaktivasyonlarda, makrofajlarda bağışıklığı destekleyici sitokininlerin üretimindeki artış üzerinde, hücreye uygulanan isıl işlemin engel oluşturmadiğı, böylece paraprobiyotiğin bağışıklığ olumlu yönde etkilediği yorumu literatürde bildirilmiştir (de Almada vd., 2016).

Cansiz hücreler olan paraprobiyotiklerin elde edilmesinde kullanılan inaktivasyon yöntemlerinin değerlendirildiği bir çalışmada bakteriler $60^{\circ} \mathrm{C}$ 'de 2 saat 1 sı şoku, 2.5 saat boyunca UV uygulaması ve formalin $(\% 1 \mathrm{v} / \mathrm{v})$ uygulaması olmak üzere 3 farklı yolla inaktive edilmiştir. Çalışma sonunda, 1sıl işlem görmüş formun en iyi sonucu verdiği belirtilmiştir (Kamilya vd., 2015). Fujiki vd. (2012) tarafindan yapılan bir çalışmada, 1sı ile inaktive edilerek elde edilmiş paraprobiyotik $L b$. plantarum L-137 uygulamasının, bağışıklığı destekleyici IL12p40 sitokininin üretimini, hücre yapısındaki teikoik asit bileşiminin uyardığ1 ve in vitro immünomodülasyon aktivitesini geliştirdiği gözlenmiştir. Araştırıcılar uygulanan isının bu asidin bileşimi üzerindeki etkisini netleştirmede önemli olduğunu vurgulamışlardır. Yapılan bir başka çalışmada $1 s ı$ ile inaktive edilmiş farklı laktik asit bakteri suşlarının immünostimülasyon özelliklerinin stabilitesinin, 1sıya maruz 
bırakıldığında ve suşa bağlı olarak farklılık gösterdiği belirlenmiş ve bu farklilığın lipoteikoik asit ve peptidoglikan gibi hücre çeperi bileşenlerinde meydana gelen değişikliklerle ilişkili olduğu belirtilmiştir (Ou vd., 2011). Hem canl1 hem de 1 s1 ile inaktive edilmiş $L$ b. brevis B13-2 yapılan çalışma sonucunda, her iki formun da antioksidan aktivite gösterdiği, paraprobiyotik formun ise hem stabilite hem de immünomodüle edici aktivite sergilediği ve bunların ışığında paraprobiyotiklerin fonksiyonel bileşenler olarak kullanılabileceği yorumu yapılmıştır (Song vd., 2020).

Bifidobacterium bifidum BGN4'ün hücre fraksiyonlarının postbiyotik özelliklerinin Lee vd. (2002) tarafindan incelendiği araştırmada, dört farklı fraksiyonun (tüm hücre, hücreden arındırılmış süpernatant, saflaştırılmış hücre duvar1 ve kültür süpernatant) her biri için farklı immün reaksiyon gösteren immünoregülasyon yetenekleri rapor edilmiştir. Balzaretti vd. (2017) tarafindan yapılan çalışmada, Lb. paracase $i$ DG'den elde edilen postbiyotik bir ekzopolisakkaridin, insan monosit hücre hattı Tamm-Horsfall protein 1'de (THP-1) proinflamatuar sitokinlerin gen ekspresyonunu artırarak immünostimülan özellikler sergilediği bildirilmiştir. Qi vd. (2020), yüzey tabakası proteini, genomik DNA ve metillenmemiş sitozin-fosfat-guanin içeren oligodeoksinükleotid dahil olmak üzere $L b$. rhamnosus GG'den elde edilen farklı postbiyotik bileşiklerin immünomodülatör özelliklerini değerlendirmiş ve çoğu postbiyotik fraksiyonunun olumlu etkiler gösterdiğini belirtmişlerdir.

Yapılan araştırmalar sadece in vitro çalışmalar ile sinırlı değildir. Literatürde canlı olmayan mikroorganizma ve bunların preparatlarının oral yolla alındığında deneklerin sağlığ1 üzerindeki etkilerin araştırıldığı çalışmalar da bulunmaktadır. Oral yolla alınan LAB gibi belirli tipte bağırsak stimülatörlerinin oral yolla alınması ile bağırsak fonksiyonunun modifiye edilmesi mümkün olur. $\mathrm{Bu}$ olası fonksiyonel değişiklikler, otonom sinir sistemi, endokrin sistem ve bağışıklık sistemi yoluyla tüm vücudun çeşitli biyolojik işlevlerini etkileyebilir (Sampson ve Mazmanian, 2015). Arai vd. (2018) yaptıkları çalışmada paraprobiyotik $L b$. paracasei MC1849 uygulanmasinın, farelerin bağırsak dokularında antijene özgü IgA üretimini iyileştirdiğini, bu paraprobiyotiğin, edinilmiş bağışıklık tepkilerini geliştirme potansiyeline sahip olduğunu bildirmişlerdir.

Yapılan bir çalışmada, inaktive edilmiş Lactococcus lactis H61'in oral yoldan farelere 4 ay boyunca verilmesinin bağışıklı̆g1 olumlu etkileyip kemik dansititesindeki azalma, cilt ülserlerinin görülme sıklığ1, saç dökülmesi gibi yaşlanmaya dair bazı belirtilerin üstesinden gelme potansiyeli olduğu bildirilmiştir (Kimoto-Nira vd., 2007). Benzer bir başka çalışmada, yaşlandırılmış farelere 10 $\mathrm{mg} /$ gün dozda $\left(1 \times 10^{11} \mathrm{KOB} / \mathrm{g}\right)$ paraprobiyotik Lb. gasseri TMC0356 oral yolla diyetlerinin içine eklenmiş ve bunun sonucunda paraprobiyotik laktobasillerin, konakçı hayvanlarda hücre aracilı bağışıklığ1 artırabileceğini ve dolayısıyla yaşa bağl1 immün yaşlanmayı (yaşlanmaya bağlı olarak bağışıklı̆ın bozulması) değiştirebileceğini göstermiştir (Kawase vd., 2011).

\section{GASTROINNTESTINNAL SISTEM ÜZERİNE YAPILMIŞ ÇALIŞMALAR}

Bağırsak mikrobiyotası; insan vücudunun metabolik, sindirim, immünolojik süreçlerinde ve patojen mikroorganizmaları engellemede önemli bir rol oynar. Bağırsak mikrobiyotasının sağlığ1 ve dengesinin iyileştirilmesinde tupk1 probiyotikler gibi paraprobiyotiklerin ve postbiyotiklerin de rol oynadığ1 yapılan çalışmalarla görülmüştür (Wegh vd., 2019). Bu nedenle, probiyotiklere alternatif olarak paraprobiyotik ve postbiyotik kullanımı popüler olmaya başlamıştır. Bağırsak mukozasının in vitro modellerinde 1sı ile öldürülmüş çeşitli probiyotik suşların kombinasyonunun uygulanmasının; patojen bakterilerin mukozaya yapışmasını önleyerek, paraselüler geçirgenliğin artmasını engelleyerek, membran bütünlüğünün restorasyonunu ve sitokin gen ekspresyonunu modüle ederek bağırsak hücrelerini Escherichia coli enfeksiyonundan koruduğu literatürde öne sürülmüştür (de Servi ve Ranzini, 2017).

Bağırsak bariyer bütünlügü ile alakalı paraprobiyotikler ve postbiyotiklerin potansiyel kullanımı ile ilgili çeşitli in vitro çalışmalar 
mevcuttur. Is1 ile inaktive edilmiş çeşitli paraprobiyotik bakterileri ( $L b$. bulgaricus, $L b$. acidophilus ve Streptococcus thermophilus) içeren yoğurt tüketiminin etkisinin in vitro olarak hücre kültürleri üzerinde araşturıldığı bir çalışmada, insan intestinal Caco-2 hücrelerinde bağırsak epitel bariyer fonksiyonunun bozulmasinı önlemede paraprobiyotiklerin önemli ölçüde etkili olduğu bildirilmiştir (Zeng vd., 2015). KZYA, safra asitleri, poliaminler ve aril hidrokarbon reseptör (AhR) ligandlar1 gibi postbiyotik olan metabolitler, hem immün olan hem de olmayan bağırsak hücreleri ile birlikte bağırsak mikrobiyomunu etkilemenin yanı sıra gastrointestinal sistemin bariyer yüzeyini korumak, doğuştan gelen ve uyarlanabilir konakç1 immün yanıtlarını modüle etmek gibi çeşitli işlevlere de sahiptir (Postler ve Ghosh, 2017). KZYA'nin, bağırsak mukozal bariyerinin bütünlüğünü koruduğu, antienflamatuar etkileri olan histon deasetilaz inhibitörleri olduklarından doğal bağışıklıkta ve adaptif bağırsak bağışıklığında önemli bir rol oynadığ1 literatürde belirtilmiştir (Koh vd., 2016; Riwes ve Reddy., 2020). Graft Versus Host Hastalığ1 (GVHH); kök hücre naklinden sonra donörün kemik iliği ya da kan kök hücresinde bulunan $\mathrm{T}$ lenfositlerle, alıcının doku grubu antijenleri arasındaki etkileşim sonucu oluşan, donörden alınan $\mathrm{T}$ lenfositlerinin alıciyı (host) yabanc1 olarak algilaması nedeniyle immün hücrelerinde hasar meydana getiren önemli bir komplikasyondur. Akut ya da kronik olarak sinıflandırilabilmektedir. Farelerde deneysel olarak oluşturulan akut GVHH'de; mikrobiyel metabolitlerin özellikle de KZYA'nin, intestinal epitel hücrelerinde azaldiğ1 gösterilmiştir. KZYA'den bütirat ve propiyonatın doğrudan verilmesinin ya da bağırsakta bu metabolitleri (özellikle de bütirat) üreten bakterileri arttırmanın, farelerde akut GVHH şiddetinde azalma sağladığı gösterilmiştir (Mathewson vd., 2016; Fujiwara vd., 2018).

İnflamatuar bağırsak hastalığının (IBH) iki formu olan Crohn hastalığı ve ülseratif kolit için bazı paraprobiyotiklerin probiyotikler gibi fayda sağladığını gösteren çalışmalar literatürde mevcuttur. Yapılan bir çalışmada, 1sı ile inaktive edilmiş $\left(121^{\circ} \mathrm{C}\right.$ 'de 20 dakika) Lb. brevis
SBC8803'ün, kolitli farelerin bağırsak yaralanmaları üzerindeki etkisi araştırılmıstır (Ueno vd., 2011). Paraprobiyotik uygulamasının, oksidatif stres altında bağırsak epitelinin bariyer fonksiyonunu geliştirdiği, bu nedenle paraprobiyotik uygulanmış kolitli farelerde inflamasyonu ve intestinal hasarı azalttı̆̆, bağırsak iltihabını iyileştirirken bağırsak homeostazisini de başarıly sürdürmeye yardımcı olduğu ve probiyotikler gibi bağırsakta kolonize olmadan sağlık etkisi yarattığı görülmüştür. Araştırıcılar, proinflamatuar sitokinlerin düzenlenmesi ve hücrelerin farklılaşturlması yoluyla bağırsak iltihabının iyileştiği yorumunu yapmışlardır. Benzer bir sonuç Chiu vd. (2013) tarafindan yapılan bir çalışmada da görülmüştür. Çalışmada, paraprobiyotik $L b$. plantarum un $\left(10^{7} \mathrm{KOB} / \mathrm{ml}\right)$ in vitro olarak uygulamasının insan intestinalindeki Caco-2 hücrelerine ait gen ekspresyonlarının düzenleyerek inflamasyonu inhibe ettiği, Gram negatif bakteriler tarafindan salgilanip enflamatuar1 indükleyen lipopolisakarite karşı (LPS) bağırsağın dayanımını arttırdığı bildirilmiştir. Aktif ülseratif kolite ve bu hastalığın alevlenmelerine karşı Bifidobacterium spp. ile fermente edilmiş sütteki paraprobiyotik Bifidobakterilerin etkisi Imaoka vd. (2008) tarafindan yapilan bir çalışmada araştırılmıştur. Çalışmada, paraprobiyotik B. breve ve B. bifidum uygulanmasinın, antienflamatuar bir sitokin olan interlökin 10 (IL-10) üretimini tetiklediği ve epitelyal hücrelerde proinflamatuar bir sitokin olan interlökin 8 (IL-8) salgılanmasını baskıladığ1 gözlenmiştir. Postbiyotiklerin kolondaki etkisi üzerine yapılan bir çalışmada, miyojenik hasara neden olan lipopolisakkaritlerden insan kolonundaki düz kas hücreleri $L b$. rhamnosus'un postbiyotik reaksiyonların gerçekleşmesine aracilik eden postbiyotik kimyasal maddeleri koruduğu Cicenia vd. (2016) tarafindan belirtilmiştir. Çalışmalar sonucunda paraprobiyotiklerin ve/veya bunların hücre duvarı özütlerinin, canlı bakterilere benzer yollar ile iltihabı hafifletebildiği sonucuna ulaşılmaktadır.

Paraprobiyotiklerin ve postbiyotiklerin etkisinin araştrrldığ1 sağlık problemlerinden birisi de kolon ve mide kanseridir. Literatürde yapilan çalışmalarda, farklı paraprobiyotik Lactobacillus 
spp. fraksiyonlarının, isıyla inaktive edilmiş hücrelerinin, hücre duvarının, peptidioglikan ve sitoplazmatik fraksiyonların insan kanser hücre hatlarına karşı antiproliferatif bir etki gösterebildiği belirtilmiştir (de Almada vd., 2016, Ashwini vd., 2019). Postbiyotikler ile kolon kanseri hücrelerine karşı yapılan çalışmalarda da paraprobiyotiklere benzer olarak antiproliferatif etkiler kanıtlanmış ve bu etkilerin büyük olasılıkla bağışıklık tepkilerinin düzenlenmesi yoluyla olduğu yorumu literatürde yapılmıştır (TiptiriKourpeti vd., 2016). Maghsood vd. (2020) tarafından yapilan bir çalışmada, $L b$. reuteri PTCC 1655 ten üretilen postbiyotiklerin (hücresiz süpernatant) ve paraprobiyotiklerin (1sil işlem görmüş ve sonike edilmiş), kolon kanseri kök hücre benzeri hücreler (HT29-ShE) üzerinde baskılayıcı etkiler göstererek apoptozu (kontrollü hücre ölümünü) artırdığı gözlenmiştir. Probiyotik S. thermophilus ve onun postbiyotik EPS'leri ile yapılan bir çalışmada; Helicobacter pylori adezyonununun azaldığı, yapışkan insan mide adenokarsinom epitel hücre hattunda (AGS hücreleri) sitokin IL-8'in modülasyonu ile enflamasyon hafifleyerek antienflamatuar etkinin görüldüğgu bildirilmiştir (Marcial vd., 2017). Benzer sonuçlar literatürde başka çalışmalarda da görülmüş ve postbiyotik/paraprobiyotik uygulamasının, insan kolon karsinom hücre hatt1 ile kolon adenokarsinom hücre hattı üzerinde apoptozu arttırdığ1 bildirilmiştir (Karimi Ardestani vd., 2019; Nozari vd., 2019).

Literatürde canlı olmayan mikroorganizma ve bunların prepraratlarının oral yolla tüketiminin, deneklerin bağırsak sağlığ1 ve stabilitesi üzerine olan etkisinin araştırıldığ1 birçok çalışma bulunmaktadır. Diyet yolu ile tüketimi ile bağırsak mikrobiyotasının hem kompozisyonunun hem de metabolik aktivitesinin gelişmesine paraprobiyotik tüketiminin olumlu katkıda bulunduğu, bu katkıların peptitler, teikoik asitler gibi hücre duvarı bileşenlerinden dolayı olduğu yapılan çalışmalarla literaütrde belirtilmiştir. Yapılan bir çalışmada, hızlandırılmış şekilde yaşlandırılmış farelerin diyetine $0.5 \mathrm{~g} / \mathrm{kg}$ 'da $1 \mathrm{~s} 1$ ile inaktive edilmiş $L$ c. lactis ssp. lactis G50 ilave edilmiş paraprobiyotik tüketiminin bağırsakta zararlı bakterilerinin gelişimini baskıladığı, bu farelerin bağırsak mikrobiyotasını iyileştirdiği, bağırsakta $\mathrm{H}_{2} \mathrm{~S}$ üreten bakterilerin çoğalmasını engellediği belirlenmiştir (Kimoto-Nira vd., 2009). Yapılan klinik bir çalışmada ise 2 hafta boyunca günlük olarak paraprobiyotik kullanan katılımcilarda, günlük $\geq 10 \mathrm{mg}$ doz paraprobiyotik alımının, bağırsak ortamında gözlenen Bacteroides fragilis gibi bakterilerin seviyesini önemli şekilde azalttı̆̆1, bağırsak hareketlerini ise arttırdığ1 gözlenmiştir (Asama vd., 2016). Ülseratif kolit üzerinde yapılan çalışmada, oral olarak hem canlı hem de paraprobiyotik Lb. plantarum Zhang-LL verilen farelerde; serumda proinflamatuar sitokin miktarının ve kolon dokusunda bağırsak geçirgenliğinin azaldığı, intestinal mikrobiyota stabilitesinin korunduğu ve böylece farelerde ülseratif kolit semptomlarının hafiflediği gözlenmiştir (Jin vd., 2020).

Bağırsak bariyerini korumak ve bakteriyel translokasyonu azaltmak için paraprobiyotik kullanımı ile ilgili yapılan bir çalısmada, ısı ile etkisiz hale getirilmiş Saccharomyces boulardii $\left(10^{9}\right.$ $\mathrm{KOB} / \mathrm{ml}$ ) uygulamasının, bağırsak geçirgenliğini koruyarak ve bakteriyel translokasyonu azaltarak farelerde bağırsak bariyerini koruduğu belirtilmiştir. Bu faydaların çalısmada kullanılan maya hücresinin duvarına bağlı olduğu sonucuna varılmıştır. $\mathrm{Bu}$ nedenle etki mekanizmasında, hücre yapısı bileşenlerinin hücre metabolizmasından daha fazla etkili olduğu yorumu yapilmıştır (Generoso vd., 2011). Viseral ağr1 (iç organlardan kaynaklanan ağnllar) rahatsızlığına karşı paraprobiyotiklerin etkisinin araştırıldığı bir çalışmada, sıçanlarda probiyotik veya paraprobiyotik $L b$. reuteri'nin $1 \mathrm{~s} 1\left(80^{\circ} \mathrm{C}^{\prime}\right.$ de 20 $\mathrm{dk}$ ) veya gama ışını ile etkisiz hale getirilip etkileri araştırılmıştır. Araştırıcılar bu uygulamaların, bağırsaktaki enterik sinirler üzerinde olumlu etki ettiğini, kolorektal distansiyonun (kalın bağırsakta gaz birikimi sonucu şişkinlik ve ağrı) neden olduğu iç organlardan kaynaklanan ağnıları (viseral ağrryı) önleyebildiğini, lipoteikoik asit gibi bakteri hücre duvarı bileşenlerinin pro ve antienflamatuar immün tepkilerini düzenleyebileceğini belirtmişlerdir (Kamiya vd., 2006).

Paraprobiyotik ve postbiyotik kullanılarak üretilmiş bazı ilaçların, sindirim sistemi 
rahatsızlıkları üzerindeki etkilerini değerlendirmek için çalışmalar yapılmıştur. İshal tedavisi amacıyla 1s1 ile inaktive edilmiss liyofilize $L b$. acidophilus içeren paraprobiyotik kapsüller, Fransa'da ticari olarak geliştirilmiş ve insanlarda kronik ishalin tedavisinde kullanılmıştır. Bu kapsülün çocuklarda viral veya bakteriyel kaynaklı ishalin tedavisinde, hastalık süresinin azaltılmasında, irritabl bağırsak sendromu olan hastalarda dışkı kıvamının iyileştirilmesinde fayda sağladığı belirlenmiştir (de Almada vd., 2016). Araştırıcılar bu ticari kapsülün etki şeklinin, $L b$. acidopbilus'un patojenik mikroorganizmanın yapsşma ve istilasına karş1 kolitli mukozayı koruma kabiliyeti geliştirmesiyle ilgili olduğunu öne sürmüşlerdir. $L b$. rhamnosus V'den ekstrakte edilen muramil peptidleri içeren ticari bir postbiyotik ilacın, çocuklarda gastrointestinal rahatsılılı̆ın giderilmesine yardımc1 olduğu; $B$. longum, $S$. thermophilus ve $L b$. plantarum'un hücre duvarı lizatlarını içeren bir ilacın çocuklarda disbiyozis (bozulmuş, sağlıksız mikrobiyota) ve otizmi önlemede faydalı olduğu; $L b$. acidophilus ve $L b$. helveticus'un ürettiği KZYA'ni içeren bir başka ilacın ise kronik gastritli hastalarda sağlıksız mikrobiyotayı düzenlediği yapılan çalışmalar sonucunda bildirilmiştir (West vd., 2013; Omarova vd., 2014). Kabız veya bağırsak hareketliliği artmış olan bireylerde 1sı ile inaktive edilmiş Lb. gasseri CP2305'i içeren fermente sütün (\%10 skimmilk+\%0.25 yeast ekstrakt) etkisi araştırlmışıtır (Sawada vd., 2016). Çalışma sonunda, 3 hafta boyunca, özellikle kabız olan deneklerde iyileşmeler görülmüş ve bu çalışma ile araştırıcılar, gıda yolu ile paraprobiyotik tüketiminin kabızlı̆̆a eğilimi olan hastalarda bağırsak fonksiyonunu düzenlediğini bildirmişlerdir.

\section{PSIKKOLOJIYYI DÜZENLEYİCI ETKİSİ ÜZERİNE YAPILAN ÇALIŞMALAR}

Hayvan ve insan çalışmalarından elde edilen çeşitli kanıtlar, bağırsak mikrobiyotasının otonom sinir sisteminin faaliyetlerini değiştirebileceğini ve bağırsak fonksiyonlarını, serotonin biyosentezi ve ruh sağlığ1 durumunu değiştirebileceğini göstermiştir. $\mathrm{Bu}$ tedaviler için kullanılan canlı mikroorganizmalara "psikobiyotik" denilmektedir (Sampson ve Mazmanian, 2015; Obata ve Pachnis, 2016).
Yapılan bir çalışmada, canlı formda veya 1s1 uygulamas1 ile $\left(100^{\circ} \mathrm{C}^{\prime} \mathrm{de} 30 \mathrm{dk}\right)$ öldürülen $L b$. paracasei PS23'ün (10 $\mathrm{KOB} / 0.2 \mathrm{ml} \quad \mathrm{doz})$ antidepresan benzeri etkileri araştırılmıştır. Hem canlı hem de paraprobiyotik PS23'ün anksiyete ve depresyon benzeri davranışları tersine çevirebildiği, depresyon yönetimi için potansiyel bir psikobiyotik olabileceği öne sürülmüştür (Wei vd. 2019). Warda vd. (2019) 1sıl işlem görmüş $L b$. fermentum ve $L b$. delbrueckii suşlarını içeren bir paraprobiyotik ürününün (ADR-159) farelerde kullanımının, stres hormonu kortikosteronun seviyesini düşürdüğü ve hayvanların sosyalliğini arturdığını gözlemlemişlerdir. Benzer bir çalışmada, araştırıcılar paraprobiyotiklerin $L b$. helveticus MCC1848'in subkronik ve hafif sosyal yenilgi stres modelli farelerde anksiyolitik veya antidepresan benzeri etkiler sağladığını bulmuşlardır (Maehata vd., 2019). Varian vd. (2017), Lb. reuteri ATCC-PTA-6475'ten elde edilen postbiyotiklerin, farelerde oksitosin seviyelerini artırdığını ve kortikosteronu azalttığın, bunlara ek olarak farelerin cilt yaralarında daha hızlı iyileşme sağladığını gözlemlemişlerdir.

Nishida vd. (2017a) tarafindan yapılan çalışmada, paraprobiyotik Lb. gasseri CP2305 her bir test içeceği kutusunda $1 \times 10^{10}$ bakteri/kutu olacak şekilde hazırlanan içecekten katılımcılar 5 hafta boyunca günde 1 kere tüketmiştir. Çalışmada paraprobiyotik CP2305'in etkilerinde stres yanitlarını düzenleyen potansiyel bir paraprobiyotik olduğu sonucuna varmışlardır. Benzer şekilde başka bir çalışmada paraprobiyotik Lb. gasseri CP2305 1×1010 KOB/ml dozda olacak şekilde hazırlanıp, içeceklere eklenerek sınav stresi altında olan bireylere 12 hafta boyunca içirilmiş ve bunun sonucunda uyku kalitesinin önemli ölçüde arttığ1, parasempatik sinir aktivitesindeki iyileşmeye ek olarak stresli koşullar altında bağırsak alışkanlıklarının normalleştiği tespit edilmiştir (Nishida vd., 2017b). Fiziksel ve zihinsel stres altındaki atletler ile yapilan bir çalışmada, atletler inaktive edilmiş $L$ b. gasseri CP2305 $\left(1 \times 10^{10}\right.$ $\mathrm{KOB} /$ kutu) içeren özel hazırlanmış içecekleri 12 hafta boyunca tüketmişlerdir. Çalışma sonucunda katılımciların yorgunluklarının önemli ölçüde 
azaldığ1, endişe ve depresif ruh hallerinin hafiflediği görülmüsstür (Sawada vd., 2019)

\section{DİĞER SAĞLIK ETKİLERİ ÜZERİNE YAPILMIŞ ÇALIŞMALAR}

Çeşitli paraprobiyotik uygulamalarının; alerjik rinit semptomlarına karşı baskılayıcı etki yapıp hafiflettiği, alerjik solunum yolu hastalıklarının önlenmesi ve tedavisinde potansiyel sağladığı, konakçının savunma mekanizması olan bağırsak immünitesini düzenlediği, solunum yollarının aşırı duyarlılığını azalttığı, yaşlı erişkinlerde yaygın soğuk algınlığı oranını düşürdüğü ve genel sağlık durumunun iyileştirdiği gözlenmiştir (de Almada vd., 2016). Y1llarca süren alerjik rinitli hastaların semptomlarının hafifletilmesinde paraprobiyotik uygulamasının olası etkisi klinik bir çalışmada incelenmiştir. Çalışmada 1sı ile inaktive edilmiş $L b$. plantarum YIT 0132 eklenen bir narenciye suyunu katılımcilar 8 hafta boyunca günde bir kez tüketmişlerdir. Sonuçlar, LP0132 tüketen kat1lımcilarin nazal semptom skorunda ve tıkalı burun skorunda önemli bir azalma olduğunu göstermiştir (Harima-Mizusawa vd., 2016).

Paraprobiyotik uygulamasının, farelerde diş çürümesi üzerine etkisinin araştırıldığ1 bir çalışmada; diş çürügü oluşumunun azaldığ1, ayrıca oral mikrobiyotayı değiştirmek için potansiyel olarak kullanılabileceği gösterilmiştir (Sañudo vd., 2017). Yapılan başka bir çalışmada 12 hafta boyunca katılimcilara oral yolla isi ile inaktive edilmiş Lb. plantarum L-137'den günlük $10 \mathrm{mg}$ verilmiş ve periodontal tedavideki sonuçları incelenmiştir. Çalışma sonucunda, hastalarda periodontal ceplerin en dip noktasinda azalmalar gözlenerek olumlu sonuçlar elde edilmiştir (Iwasaki vd. 2016).

Laktoz intoleransı olan çocuklarda paraprobiyotik (Dialac) içeren poşet uygulamasının etkisi araştırılmıştır. Yapılan uygulamanın laktoz intoleranslı çocuklarda laktoz intoleransını gösteren hidrojen solunum test sonuçlarını azalttığ1 görülmüsstür (Rampengan vd., 2010). Alkolle tetiklenen karaciğer hastalı̆̆ına paraprobiyotiklerin etkisinin araştırıldığ çalışmalarda, paraprobiyotik tüketiminin alkolle indüklenen karaciğer hastalığını iyileştirebildiği görülmüştür (Segawa vd., 2008). Yapılan bir çalışmada, paraprobiyotik takviyesinin, yüksek yoğunluklu egzersiz sırasında, üst solunum yolu enfeksiyon hastalıklarının görülme sıklığını azalttı̆̆1, semptomlar1 hafiflettiği, yorgunluk hissini azalttığı gösterilmiştir (Komano vd., 2018).

Atopik dermatit tedavisine yönelik yapılan çalısmalarda, bazı probiyotik ve paraprobiyotiğin oral yolla uygulanmasinin cilt iltihabı ve lezyonları inhibe ettiği bildirilmiştir. Moroi vd. (2011) tarafindan yapılan bir çalışmada, 12 hafta boyunca paraprobiyotik içeren toz formda diyet takviyesi uygulanan hastalarda, diğerlerine göre apotik dermatit semptomlarının ve cilt lezyonlarının ciddiyetinin azaldığı görülmüştür. Cilt üzerine etkisinin araştırıldığ 1 bir başka çalışmada da paraprobiyotiğin insan keratinositindeki cilt nemlendirme aktivitesi değerlendirilmiş ve nemlendirici ürünlerde fonksiyonel bir bileşen olarak paraprobiyotik kullanımına ilişkin ön veriler sunulmuştur (Kim vd., 2020).

Nakamura vd. (2016) tarafindan yapilan obez fare modelinde, 12 hafta boyunca parçalanmış Lactobacillus amylovorus CP1563 ile muamelenin, plazmadaki LDL-kolesterol ve trigliserit seviyelerini düşürdüğü, ateroskleroz indeksini önemli ölçüde azalttığ1 ve plazma HDL-kolesterol seviyesini yükselttiğini gözlenmiştir. Araştırıcılar, parçalanmış CP1563'ün dislipideminin önlenmesi ve tedavisi için bir aday olabileceği sonucuna varmışlardır. Muramil dipeptid bazlı postbiyotiklerin obez fareler üzerinde denendiği bir çalışmada ise adipoz inflamasyonu ve glikoz intoleransının azaldığı gözlenmiştir (Cavallari vd., 2017).

\section{SONUÇ}

Paraprobiyotikler ve postbiyotikler ile yapılan çalışmalarda, genel anlamda sağlık yönünden olumlu ve probiyotiklerle benzer etkiler görülmüştür. $\mathrm{Bu}$ etkileri; hücre içi bileşenler, hücre duvarı bileşikleri, elde edilen hücre özütleri ve metabolitlerinin, bağışıklık sistemini hızlandırma yolu ile sağladığı, bağırsak hücrelerine yapışmayı arttırdığı yapılan çalışmalarda görülmektedir. Bütün bu çalışmaların ışığında paraprobiyotik ve postbiyotik tüketiminin, 
probiyotikler gibi sağlık faydaları olduğu anlaşılmaktadır. Probiyotiklerin etkinliğini sınırlandıran ssıl işlemlerden etkilenmemesi ve kısa raf ömrü gibi sorunları olmaması nedeniyle paraprobiyotik ve postbiyotiklerin kullanım alanı giderek genişlemektedir. Ancak paraprobiyotik/postbiyotik takviyesinin sağlıkla ilgili iddialannı desteklemek ve gerekli olan spesifik bir dozu ortaya koymak için iyi tasarlanmış randomize, plasebo kontrollü insan ve klinik müdahale denemeleri ile metabolomik çalısmalara daha fazla ihtiyaç duyulmaktadır.

\section{ÇIKAR ÇATIŞMASI BEYANI}

Yazarlar, makalenin herhangi bir kişi veya kurumlar ile çıkar çatışması olmadığını beyan ederler.

\section{YAZAR KATKILARI}

Makalenin derlenmesinde, yazılmasinda ve yayınlanmasında tüm yazarlar katkı sağlamışlardır.

\section{KAYNAKLAR}

Aguilar-Toalá, J.E., Estrada-Montoya, M.C., Liceaga, A.M., Garcia, H.S., González-Aguilar, G.A., Vallejo-Cordoba, B., vd. (2019). An insight on antioxidant properties of the intracellular content of Lactobacillus casei CRL-431. LWTFood Sci Technol, 102: 58-63, doi: 10.1016/j.lwt.2018.12.015.

Aguilar-Toalá, J.E., Garcia-Varela, R., Garcia, H.S., Mata-Haro, V., González-Córdova, A.F., Vallejo-Cordoba, B., Hernández-Mendoza, A. (2018). Postbiotics: An evolving term within the functional foods field. Trends Food Sci Technol, 75:105-114, doi: 10.1016/j.tifs.2018.03.009.

Anonymous (2006). Türk Gıda Kodeksi. Gıda Maddelerinin Genel Etiketleme ve Beslenme Yönünden Etiketleme Kurallan Tebliğinde Değişiklik Yapılması Hakkında Tebliğ (2006/34). Tarım ve Köyişleri Bakanlığı. 7 Temmuz 2006 tarih ve 26221 sayll Resmî Gazete, Ankara.

Arai, S., Iwabuchi, N., Takahashi, S., Xiao, J.-Z., Abe, F., Hachimura, S. (2018). Orally administered heat-killed Lactobacillus paracasei MCC1849 enhances antigen-specific IgA secretion and induces follicular helper $\mathrm{T}$ cells in mice. PloS one, 13(6): 0199018, doi: 10.1371/journal.pone.0199018.

Asama, T., Kimura, Y., Kono, T., Tatefuji, T., Hashimoto, K., Benno, Y. (2016). Effects of heatkilled Lactobacillus kunkeei YB38 on human intestinal environment and bowel movement: a pilot study. Benef Microbes, 7(3): 337-44, doi: 10.3920/BM2015.0132.

Ashwini, A., Ramya, H.N., Ramkumar, C., Reddy, K.R., Kulkarni, R.V., Abinaya, V., Raghu, 362 A.V. (2019). Reactive mechanism and the applications of bioactive prebiotics for human 363 health. J Microbiol Methods, 159, 128-137. doi: 10.1016/j.mimet.2019.02.019

Balzaretti, S., Taverniti, V., Guglielmetti, S., Fiore, W., vd. (2017). A novel rhamnose-rich heteroexopolysaccharide isolated from Lactobacillus paracasei DG activates THP-1 human monocytic cells. J Appl Environ Microbiol 83(3): e02702-02716, doi: 10.1128/AEM.02702-16.

Baothman, O. A., Zamzami, M. A., Taher, I., Abubaker, J., Abu-Farha, M. (2016). The role of gut microbiota in the development of obesity and diabetes. Lipids Health Dis, 15(1): 1-8, doi: 10.1186/s12944-016-0278-4.

Bektas, A., Ulusoy, M., Bektaş, V. (2020a). Gıda etiketlerinde yer alan bilgilerin sağlıklı algilanma (health halo) etkisi. GID A, 45(3): 590-599, doi: 10.15237/gida.GD20045.

Bektaş, A., Ulusoy, M., Bektaş V. (2020b). Gıda Takviyesi Olarak Probiyotik, Paraprobiyotik, Postbiyotik ve Prebiyotiklerin Sağllk Üzerine Etkileri. Türkiye 13.Gida Kongresi, 21-23 Ekim 2020, Çanakkale, Türkiye, 20 s.

Buran, İ. (2020). Probiyotik ve Prebiyotiklerin Sinbiyotik Kullanımının İnek ve Keçi Sütünden Üretilen Kefirlerin Kalite Özellikleri Üzerine Etkisi. Ankara Üniversitesi Fen Bilimleri Enstitüsü Doktora Tezi, Ankara, Türkiye, 175 s.

Cavallari, J. F., Fullerton, M. D., Duggan, B., vd. (2017). Muramyl dipeptide-based postbiotics mitigate obesity-induced insulin resistance via IRF4. Cell Metab, 25: 1-12, doi: 10.1016/j.cmet.2017.03.021. 
Chiu, Y.-H., Lu, Y.-C., Ou, C.-C., Lin, S.-L., Tsai, C.-C., Huang, C.-T. (2013). Lactobacillus plantarum MYL26 induces endotoxin tolerance phenotype in Caco-2 cells. BMC Microbiol, 13:1-9, doi: 10.1186/1471-2180-13-190.

Chuah, L.O., Foo, H.L., Loh, T.C., Mohammed Alitheen, N.B., vd. (2019). Postbiotic metabolites produced by Lactobacillus plantarum strains exert selective cytotoxicity effects on cancer cells. $B M C$ Complement Altern Med, 19(1): 114, doi: 10.1186/s12906-019-2528-2.

Collado, M.C., Vinderola, G., Salminen, S. (2019). Postbiotics: facts and open questions. A position paper on the need for a consensus definition. Beneficial Microbes, 10(7): 711-719, doi: 10.3920/BM2019.0015.

Cicenia, A., Santangelo, F., Gambardella, L., Pallotta, L., Iebba, V., Scirocco, A., vd. (2016). Protective role of postbiotic mediators secreted by Lactobacillus rhamnosus GG versus lipopolysaccharide-induced damage in human colonic smooth muscle cells. J Clin Gastroenterol, 50: 140-144, doi: 10.1097/MCG.0000000000000681.

Cuevas-González, P.F., Aguilar-Toalá, J.E., García, H.S., González-Córdova, A.F., VallejoCordoba, B., Hernández-Mendoza, A. (2020). Protective effect of the intracellular content from potential probiotic bacteria against oxidative damage induced by acrylamide in human erythrocytes. Probiotics Antimicrob Proteins, 12(4):1459-1470, doi: 10.1007/s12602-02009636-9.

de Almada, C. N., Almada, C. N., Martinez, R. C. R., Sant'Ana, A. S. (2016). Paraprobiotics: Evidences on their ability to modify biological responses, inactivation methods and perspectives on their application in foods. Trends Food Sci Technol, 58: 96-114, doi: 10.1016/j.tifs.2016.09.011.

de Oliveira Coelho, B., Fiorda-Mello, F., de Melo Pereira, G. V., Thomaz-Soccol, V., vd. (2019). In vitro probiotic properties and DNA protection activity of yeast and lactic acid bacteria isolated from a honey-based kefir beverage. Foods, 8(10): 485, doi: 10.3390/foods8100485. de Servi, B., Ranzini, F. (2017). Protective efficacy of antidiarrheal agents in a permeability model of Escherichia coli-infected CacoGoblet ${ }^{\circledR}$ cells. Future Microbiol, 12(16): 1449-1455, doi: 10.2217/fmb-2016-0195.

Dunand, E., Burns, P., Binetti, A., Bergamini, C., Peralta, vd. (2019). Postbiotics produced at laboratory and industrial level as potential functional food ingredients with the capacity to protect mice against Salmonella infection. $J$ Appl Microbiol, 127(1): 219-229, doi: 10.1111/jam.14276.

Fujiki, T., Hirose, Y., Yamamoto, Y., Murosaki, S. (2012). Enhanced Immunomodulatory Activity and Stability in Simulated Digestive Juices of Lactobacillus plantarum L-137 by Heat Treatment. Biosci Biotechnol Biochem, 76(5): 918 922, doi: 10.1271/bbb.110919.

Fujiwara, H., Docampo, M.D., Riwes, M., vd. (2018). Microbial metabolite sensor GPR43 controls severity of experimental GVHD. Nat Comm, 9(1):3674., doi: 10.1038/s41467-01806048-w.

Generoso, S.V., Viana, M.L., Santos, R.G., Arantes, R.M.E., Martins, F.S., Nicoli, J.R. (2011). Protection against increased intestinal permeability and bacterial translocation induced by intestinal obstruction in mice treated with viable and heat-killed Saccharomyces boulardii. Eur J Nutr, 50: 261-269, doi: 10.1007/s00394010-0134-7.

Harima-Mizusawa, N., Kano, M., Nozaki, D., Nonaka, C., Miyazaki, K., Enomoto, T. (2016). Citrus juice fermented with Lactobacillus plantarum YIT 0132 alleviates symptoms of perennial allergic rhinitis in a double-blind, placebo-controlled trial. Benef Microbes. 30; 7(5): 649-658, doi: 10.3920/BM2016.0003.

Imaoka, A., Shima, T., Kato, K., Mizuno, S., Uehara, T., Matsumoto, S. (2008). Antiinflammatory activity of probiotic Bifidobacterium: Enhancement of IL-10 production in peripheral blood mononuclear cells from ulcerative colitis patients and inhibition of IL-8 secretion in HT-29 cells. World J Gastroenterol, 14: 2511-2516, doi: 10.3748/wjg.14.2511. 
Iraporda, C., Errea, A., Romanin, D.E., Cayet, D., Pereyra, E., Pignataro, O., Sirard, J.C., Garrote, G.L., Abraham, A.G., Rumbo, M. (2015). Lactate and short chain fatty acids produced by microbial fermentation downregulate proinflammatory responses in intestinal epithelial cells and myeloid cells. Immunobiology, 220: 1161-1169, doi: 10.1016/j.imbio.2015.06.004.

Iwasaki, K., Maeda, K., Hidaka, K., Nemoto, K., Hirose, Y., Deguchi, S. (2016). Daily Intake of Heat-killed Lactobacillus plantarum L-137 Decreases the Probing Depth in Patients Undergoing Supportive Periodontal Therapy. Oral Health Prev Dent,14(3):207-14, doi: 10.3290/j.ohpd.a36099.

Jin, J, Wu, S., Xie, Y., Liu, H., Gao, X., Zhang, H. (2020). Live and heat-killed cells of Lactobacillus plantarum Zhang-LL ease symptoms of chronic ulcerative colitis induced by dextran sulfate sodium in rats. J Funct Foods, 71: 103994, doi: 10.1016/j.jff.2020.103994.

Kamilya, D., Baruah, A., Sangma, T., Chowdhury, S., Pal, P. (2015). Inactivated Probiotic Bacteria Stimulate Cellular Immune Responses of Catla, Catla catla (Hamilton) In Vitro. Probiotics Antimicrob Proteins, 7(2):101-106, doi: 10.1007/s12602-015-9191-9.

Kamiya, T., Wang, L., Forsythe, P., Goettsche, G., Mao, Y., Wang, Y. (2006). Inhibitory effects of Lactobacillus reuteri on visceral pain induced by colorectal distension in Sprague-Dawley rats. Gut, 55: 191-196, doi: 10.1136/gut.2005.070987.

Karimi Ardestani, S., Tafvizi, F., Tajabadi Ebrahimi, M. (2019). Heat-killed probiotic bacteria induce apoptosis of HT-29 human colon adenocarcinoma cell line via the regulation of $\mathrm{Bax} / \mathrm{Bcl} 2$ and caspases pathway. Hum Exp Toxicol, 38(9): 1069-1081, doi: 10.1177/0960327119851255.

Kawase, M., He, F., Miyazawa, K., Kubota, A., Yoda, K., Hiramatsu, M. (2012). Orally administered heat-killed Lactobacillus gasseri TMC0356 can upregulate cell-mediated immunity in senescence-accelerated mice. FEMS Microbiol Lett, 326: 125-130, doi: 10.1111/j.15746968.2011.02440.x.
Kim, H., Jeon, B., Kim, W.J., Chung, D-K. (2020). Effect of paraprobiotic prepared from KimchiderivedLactobacillusplantarumK8 on skin moisturizing activity in human keratinocyte. $J$ Funct Foods, 75: 104244, doi: 10.1016/j.jff.2020.104244.

Kimoto-Nira, H., Mizumachi, K., Okamoto, T., Sasaki, K., Kurisaki, J. (2009). Influence of longterm consumption of a Lactococcus lactis strain on the intestinal immunity and intestinal flora of the senescence-accelerated mouse. Br J Nutr, 102: 181-185, doi: 10.1017/S0007114508143574.

Kimoto-Nira, H., Suzuki, C., Kobayashi, M., Sasaki, K., Kurisaki, J., Mizumachi, K. (2007). Anti-ageing effect of a lactococcal strain: Analysis using senescence-accelerated mice. Br J Nutr, 98: 1178-1186, doi: 10.1017/S0007114507787469.

Koh, A., De Vadder, F., Kovatcheva-Datchary, P., Bäckhed, F. (2016). From Dietary Fiber to Host Physiology: Short-Chain Fatty Acids as Key Bacterial Metabolites. Cell, 165(6): 1332-1345, doi: 10.1016/j.cell.2016.05.041.

Komano, Y., Shimada, K., Naito, H., Fukao, K., Ishihara, Y., Fujii, T., Kokubo, T., Daida, H. (2018). Efficacy of heat-killed Lactococcus lactis JCM 5805 on immunity and fatigue during consecutive high intensity exercise in male athletes: a randomized, placebo-controlled, double-blinded trial. J Int Soc Sports Nutr, 2;15(1): 39, doi: 10.1186/s12970-018-0244-9.

Lee, M., J., Zang, Z.L., Choi, E.Y., Shin, H.K., Ji, G.E. (2002). Cytoskeleton Reorganization and Cytokine Production of Macrophages by Bifidobacterial Cells and Cell- Free Extracts. J Microbiol Biotechnol, 12(3): 398-405.

Maehata, H., Kobayashi, Y., Mitsuyama, E., Kawase, T., Kuhara, vd. (2019). Heat-killed Lactobacillus helveticus strain MCC1848 confers resilience to anxiety or depression-like symptoms caused by subchronic social defeat stress in mice. Biosci Biotechnol Biochem, 83(7): 1239-1247, doi: 10.1080/09168451.2019.1591263.

Maghsood, F., Johari, B., Rohani, M., Madanchi, H., Saltanatpour, Z., Kadivar, M. (2020). Antiproliferative and anti-metastatic potential of high molecular weight secretory molecules from 
probiotic Lactobacillus reuteri cell-free supernatant against human colon cancer stem-like cells (HT29-ShE). Int J Peptide Res Therapeut, 26: 2619-2631, doi: 10.1007/s10989-020-10049-z.

Malashree, L., Vishwanath, A., Shivalkar, Y., Prabha, R. (2019). "Postbiotics" - One Step Ahead of Probiotics. Int J Curr Microbiol Appl Sci, 8(01): 2319-7706, doi: 10.20546/ijcmas.2019.801.214.

Marcial, G., Villena, J., Faller, G., Hensel, A., de Valdéz, G.F. (2017). Exopolysaccharideproducing Streptococcus thermophilus CRL1190 reduces the inflammatory response caused by Helicobacter pylori. Benef Microbes, 30;8(3): 451461, doi: 10.3920/BM2016.0186.

Martín, R., Langella, P. (2019). Emerging health concepts in the probiotics field: Streamlining the definitions. Front Microbiol, 10: 1047, doi: 10.3389/fmicb.2019.01047.

Mathewson, N., Jenq, R., Mathew, A., vd. (2016). Gut microbiome-derived metabolites modulate intestinal epithelial cell damage and mitigate graftversus-host disease. Nat Immunol, 17: 505-513, doi: 10.1038/ni.3400.

Moradi, M., Mardani, K., Tajik, H. (2019). Characterization and application of postbiotics of Lactobacillus spp. on Listeria monocytogenes in vitro and in food models. LWT- Food Sci Technol, 111: 457-464, doi: 10.1016/j.lwt.2019.05.072.

Moroi, M., Uchi, S., Nakamura, K., Sato, S., vd. (2011). Beneficial effect of a diet containing heatkilled Lactobacillus paracasei K71 on adult type atopic dermatitis. J Dermatol, 38(2):131-9, doi: 10.1111/j.1346-8138.2010.00939.x.

Nakamura F, Ishida Y, Sawada D, vd. (2016). Fragmented Lactic Acid Bacterial Cells Activate Peroxisome Proliferator-Activated Receptors and Ameliorate Dyslipidemia in Obese Mice. J Agric Food Chem, 64(12): 2549-2559, doi: 10.1021/acs.jafc.5b05827.

Nataraj, B. H., Ali, S. A., Behare, P. V., Yadav, H. (2020). Postbiotics-parabiotics: the new horizons in microbial biotherapy and functional foods. Microb Cell Fact, 19(1),: 1-22, doi: 10.1186/s12934020-01426-w.
Nishida, K., Sawada, D., Kawai, T., Kuwano, Y., Sugawara, T., Rokutan, K. (2017a). Parapsychobiotic Lactobacillus gasseri CP2305 ameliorates stress-related symptoms and sleep quality. J Appl Microbiol, 123(6): 1561-1570, doi: 10.1111/jam.13594.

Nishida, K., Sawada, D., Kuwano, Y., Tanaka, H., Sugawara, T., Aoki, Y., Fujiwara, S., Rokutan, K. (2017b). Daily administration of paraprobiotic Lactobacillus gasseri CP2305 ameliorates chronic stress-associated symptoms in Japanese medical students. J Funct Foods, 36: 112-121, doi: 10.1016/j.jff.2017.06.031.

Nozari, S., Faridvand, Y., Etesami, A., Ahmad Khan Beiki, M., Miresmaeili Mazrakhondi, S. A., Abdolalizadeh, J. (2019). Potential anticancer effects of cell wall protein fractions from 29 Lactobacillus paracasei on human intestinal Caco2 cell line. Lett Appl Microbiol, 69(3): 148-154, doi: 10.1111/lam.13198.

Obata, Y., Pachnis, V. (2016). The effect of microbiota and immune system on the development and organization of the enteric nervous system. Gastroenterology, 151: 836-844, doi: 10.1053/j.gastro.2016.07.044.

Omarov, T. R., Omarova, L. A., Omarova, V. A., Sarsenova, S. V. (2014). The chronic gastritis, the dysbacteriosis and the use of Hylak forte at the treatment. Wiad Lek, 67 (2 Pt 2): 365-7.

Ou, C-C., Lin, S-L., Tsai, J-J., Lin, M-Y. (2011). Heat-Killed Lactic Acid Bacteria Enhance Immunomodulatory Potential by Skewing the Immune Response toward Th1 Polarization. $J$ Food Sci,76(5): 260-267, doi: 10.1111/j.17503841.2011.02161.x.

Palmer, C., Bik, E.M., DiGiulio, D.B., Relman, D.A., Brown, P.O. (2007). Development of the human infant intestinal microbiota. PLoS Biol, 5(7): e177, doi: 10.1371/journal.pbio.0050177.

Posadas, G. A., Broadway, P. R., Thornton, J. A., Carroll, J. A., Lawrence, A., vd. (2017). Yeast Proand Paraprobiotics have the capability to bind pathogenic bacteria associated with animal disease1. Translational Anim Sci, 1(1): 60-68, doi: $10.2527 / \operatorname{tas} 2016.0007$. 
Postler, T.S., Ghosh, S. (2017). Understanding the Holobiont: How Microbial Metabolites Affect Human Health and Shape the Immune System. Cell Metab, 26(1): 110-130, doi: 10.1016/j.cmet.2017.05.008.

Qi, S. R., Cui, Y. J., Liu, J. X., Luo, X., Wang, H. F. (2020). Lactobacillus rhamnosus GG components, SLP, gDNA and CpG, exert protective effects on mouse macrophages upon lipopolysaccharide challenge. Lett Appl Microbiol, 70(2): 118-127, doi: 10.1111/lam.13255.

Rampengan, N.H., Manoppo, J., Warouw, S.M. (2010). Comparison of efficacies between live and killed probiotics in children with lactose malabsorption. Southeast Asian J Trop Med Public Health, 41: 474-481.

Riaz Rajoka, M.S., Zhao, H., Mehwish, H.M., Li, N., vd. (2019). Anti-tumor potential of cell free culture supernatant of Lactobacillus rhamnosus strains isolated from human breast milk. Food Res Int. 123:286-297, doi: 10.1016/j.foodres.2019.05.002.

Riwes, M., Reddy, P. (2020). Short chain fatty acids: Postbiotics/metabolites and graft versus host disease colitis. Semin Hematol, 57: 1-6., doi: 10.1053/j.seminhematol.2020.06.001.

Sampson, T.R., Mazmanian, S.K. (2015). Control of brain development, function, and behavior by the microbiome. Cell Host Microbe, 17(5): 565-576, doi: 10.1016/j.chom.2015.04.011.

Sawada, D., Kuwano, Y., Tanaka, H., Hara, H., Uchiyama, Y., vd. (2019). Daily intake of Lactobacillus gasseri CP2305 relieves fatigue and stressrelated symptoms in male university Ekiden runners: A double-blind, randomized, and placebo-controlled clinical trial. J Funct Foods, 57: 465-476, doi: 10.1016/j.jff.2019.04.022.

Sawada, D., Sugawara, T., Ishida, Y., Aihara, K., Aoki, Y., Takehara, I., Takano, K. and Fujiwara, S. (2016). Effect of continuous ingestion of a beverage prepared with Lactobacillus gasseri CP2305 inactivated by heat treatment on the regulation of intestinal function. Food Res Int, 79: 33-39, doi: 10.1016/j.foodres.2015.11.032.
Sañudo, A.I., Luque, R., Díaz-Ropero, M.P., Fonollá, J., Bañuelos, Ó. (2017). In vitro and in vivo anti-microbial activity evaluation of inactivated cells of Lactobacillus salivarius CECT 5713 against Streptococcus mutans. Arch Oral Biol, 84: 58-63, doi: 10.1016/j.archoralbio.2017.09.014.

Segawa, S., Wakita, Y., Hirata, H., Watari, J. (2008). Oral administration of heat killed Lactobacillus brevis SBC8803 ameliorates alcoholic liver disease in ethanol-containing dietfed C57BL/6N mice. Int J Food Microbiol, 128: 371 377, doi: 10.1016/j.ijfoodmicro.2008.09.023.

Sharma, M. Shukla, G. (2016). Metabiotics: one step ahead of porobiotics; an insight into mechanism involved in anticarcinogenic effect in colorectal cancer. Front Microbiol, 7: 1940, doi: 10.3389/fmicb.2016.01940.

Shenderov, B.A., Sinitsa, A.V., Zakharchenko, M.M., Lang, C. (2020). Methods and techniques used for obtaining and identifying of microbial low molecular weight cellular compounds, metabolites and signaling molecules. In: Metabiotics, Springer, Cham, Switzerland, pp. 5556, Online ISBN: 978-3-030-34167-1, doi: 10.1007/978-3-030-34167-1_11.

Singhi, S. C., Kumar, S. (2016). Probiotics in critically ill children. F1000 Faculty Rev, 5: 407, doi: 10.12688/f1000research.7630.1.

Song, M.W., Chung, Y., Kim, K-T., Hong, W.S., Chang, H.J., Paik, H.D. (2020). Probiotic characteristics of Lactobacillus brevis B13-2 isolated from kimchi and investigation of antioxidant and immune-modulating abilities of its heat-killed cells. LWT, 128: 109452, doi: 10.1016/j.lwt.2020.109452.

Tanzer, J.M., Thompson, A., Lang, C., Cooper, B., Hareng, L., Gamert, A., Reindl, A., Pompejus, M. (2010). Caries Inhibition by and Safety of Lactobacillus paracasei DSMZ16671. J Dent Res, 89(9): 921-6, doi: 10.1177/0022034510369460.

Tiptiri-Kourpeti, A., Spyridopoulou, K., Santarmaki, V., Aindelis, G., Tompoulidou, E., Lamprianidou, E.E. (2016). Lactobacillus casei exerts anti-proliferative effects accompanied by apoptotic cell death and up-regulation of TRAIL 
in colon carcinoma cells. PLoS One, 11(2): e0147960, doi: 10.1371/journal.pone.0147960.

Ueno, N., Fujiya, M., Segawa, S., Nata, T., Moriichi, K., Tanabe, H. (2011). Heat killed body of lactobacillus brevis SBC8803 ameliorates intestinal injury in a murine model of colitis by enhancing the intestinal barrier function. Inflamm Bowel Dis, 17: 2235-2250, doi: 10.1002/ibd.21597.

Varian, B. J., Poutahidis, T., DiBenedictis, B.T., Levkovich, T., vd. (2017). Microbial lysate upregulates host oxytocin. Brain Behav Immun, 61: 36-49, doi: 10.1016/j.bbi.2016.11.002.

Warda, A.K., Rea, K., Fitzgerald, P., Hueston, C., Gonzalez-Tontuero, E., Dinan, T.G., Hill, C. (2019). Heat-killed lactobacilli alter both microbiota composition and behaviour. Behav Brain Res, 362, 213-223, doi: 10.1016/j.bbr.2018.12.047.

Wegh, C., Geerlings, S. Y., Knol, J., Roeselers, G., Belzer, C. (2019). Postbiotics and Their Potential Applications in Early Life Nutrition and Beyond. Int J Mol Sci, 20(19): 4673, doi: 10.3390/ijms20194673.

Wei, C.L., Wang, S., Yen, J.T., Cheng, Y.F., vd. (2019). Antidepressant-like activities of live and heat-killed Lactobacillus paracasei PS23 in chronic corticosterone-treated mice and possible mechanisms. Brain Res, 15;1711:202-213, doi: 10.1016/j.brainres.2019.01.025.

West, R., Roberts, E., Sichel, L.S., Sichel, J. (2013). Improvements in gastrointestinal symptoms among children with autism spectrum disorder receiving the Delpro ${ }^{\circledR}$ Probiotic and immunomodulator formulation. J Probiotics Health, 1: 102, doi: 10.4172/2329-8901.1000102.

Wu, X., Wu, Y., He, L., Wu, L., Wang, X. and Liu, Z. (2018). Effects of the intestinal microbial metabolite butyrate on the development of colorectal cancer. J Cancer, 9: 2510-2517, doi: $10.7150 /$ jca. 25324 .

Yangilar, F. (2015). Probiyotik mikroorganizmaların biyokoruyucu özelliği. Uludağ University Journal of The Faculty of Engineering, 20(1):119-130, doi: 10.17482/uujfe.16850.

Young, V.B. (2017). The role of the microbiome in human health and disease: an introduction for clinicians. BMJ, 356: j831, doi: 10.1136/bmj.j831.

Zeng, J., Jiang, J., Zhu, W., Chu, Y. (2015). Heatkilled yogurt-containing lactic acid bacteria prevent cytokine-induced barrier disruption in human intestinal Caco-2 cells. Ann Microbiol, 66:171-178, doi: 10.1007/s13213-015-1093-2. 